NBER WORKING PAPERS SERIES

\title{
AUDITING THE PRODUCER PRICE INDEX: \\ MICRO EVIDENCE FROM PRESCRIPTION PHARMACEUTICAL PREPARATIONS
}

Emst R. Berndt

Zvi Griliches

Joshua G. Rosett

Working Paper No. 4009

\author{
NATIONAL BUREAU OF ECONOMIC RESEARCH \\ 1050 Massachuserts Avenue \\ Cambridge, MA 02138 \\ March 1992
}

This research has been supported by grants to the National Bureau of Economic Research from the Alfred P. Sloan Foundation and from several pharmaceutical manufacturers. Rosett has also received support from an NSF Empirical PostDoctoral Associateship. We gratefully acknowledge this support, the research assistance and helpful comments from Judy Hellerstein and Barbara Campbell, as well as the cooperation of officials at the U.S. Bureau of Labor Statistics. This paper is part of NBER's research program in Productivity. Any opinions expressed are those of the authors, and not those of the National Bureau of Economic Research, the Alfred P. Sloan Foundation, or the pharmaceutical manufacturers. 
NBER Working Paper $\$ 4009$

March 1992

\title{
AUDITING THE PRODUCER PRICE INDEX: MICRO EVIDENCE FROM PRESCRIPTION PHARMACEUTICAL PREPARATIONS
}

\begin{abstract}
In this paper we focus on a mystery we uncovered while undertaking a detailed audit of the US Bureau of Labor Statistles producer price index (PPI). We summarize our puzzle as follows. From January 1984 through December 1989. the BLS price index for SIC 28341 (prescription pharmaceutical preparations) grew at an annual rale of $9.09 \%$. For purposes of comparison, we have obtained monthly price and quantity sales data on all preseription phamaceutical preparation products sold by four major US pharmaceutical manufacturers, accounting for about $24 \%$ of Lotal industry domestic sales in 1989. Using Laspeyres price index construction procedures on these data that mimic BLS methods, we find that over the same time period, the four-company price Index increased at only 6.68\% per year. Finally, when we employ a Divisia price index procedure with smoothed welghts that Incorporates new goods inmediately. the aggregate price index for these four firms grows at a rate of only $6.03 \%$ per year.
\end{abstract}

Why is it that the official BLS price index grows approximately $50 \%$ more rapidly $(9.09 \%$ vs. 6.03\%) than the Divisia price index? That mystery is the focal point of our paper.

Emst R. Berndt

NBER

1050 Massachusetts Avenue

Cambridge, MA 02138

and M.I.T.

Joshua G. Rosett

Department of Accountancy

University of Illinois

1206 South Sixth Street

Champaign, IL 61820

and NBER
Zvl Griliches

NBER

1050 Massachusetus Avenue

Cambridge, MA 02138

and Harvard University 
AUDITING THE PRODUCER PRICE INDEX:

MICRO EVIDENCE EROM PRESCRIPTION PHARMACEUTICAL PREPARATIONS

by Ernst R. Berndt, 2vI Grillches and Joshue G. Rosett

"All Index numbers which are not freaklsh or blased practically egree with each other."

$$
\text { Irving Fisher }{ }^{1}
$$

\section{INTRODUCTION}

In this paper we focus on a mystery we uncovered while undertaking a detailed audit of the US Bureau of Labor Statistics producer price Index (PPI). Our puzzle 1s sumarized In Figure 1 below. Frow January 1984 through Deceaber 1989, the BLS price Index for SIC 28341 (prescription pharmaceutical prepartions) grew at an annual rate of $9.09 x$. For purposes of comparison, we have obtalned monthly price and quantity sales data on all 2,090 proscription pharmaceutical preparation products sold by four major phermaceutical manufac.

[Insert Figure 1 Near Here)

rurers In the US, accounting for about $24 x$ of total domestic Industry ales in 1989. Using BLS-type Lespoyres price Index construction procedures on these date with splfced flxed weights, ${ }^{2}$ we find that over the same time perlod, the four-company price index Increased at only $6.68 \mathrm{x}$ per year. Finally, when we employ a Divisia price Index procedure that incorporates new goods Immediately, the aggregate four-firm price Index grows at a rate of only $6.03 x$ per year. Why is 1 that the BLS prlce Index grows approxlmately 50x more rapldly (9.09x vs. 6.03x) than the Divisla price Index? Th1. mystery is the focal point of our paper. $^{3}$

A number of factors could account for the difference. First, our four firms could be unrepresentative of the industry as a whole. Second, the products and firms sampled by the BLS could be unrepresentative of Industry transactions. This sampling discrepancy could reflect the fact that 
Index value

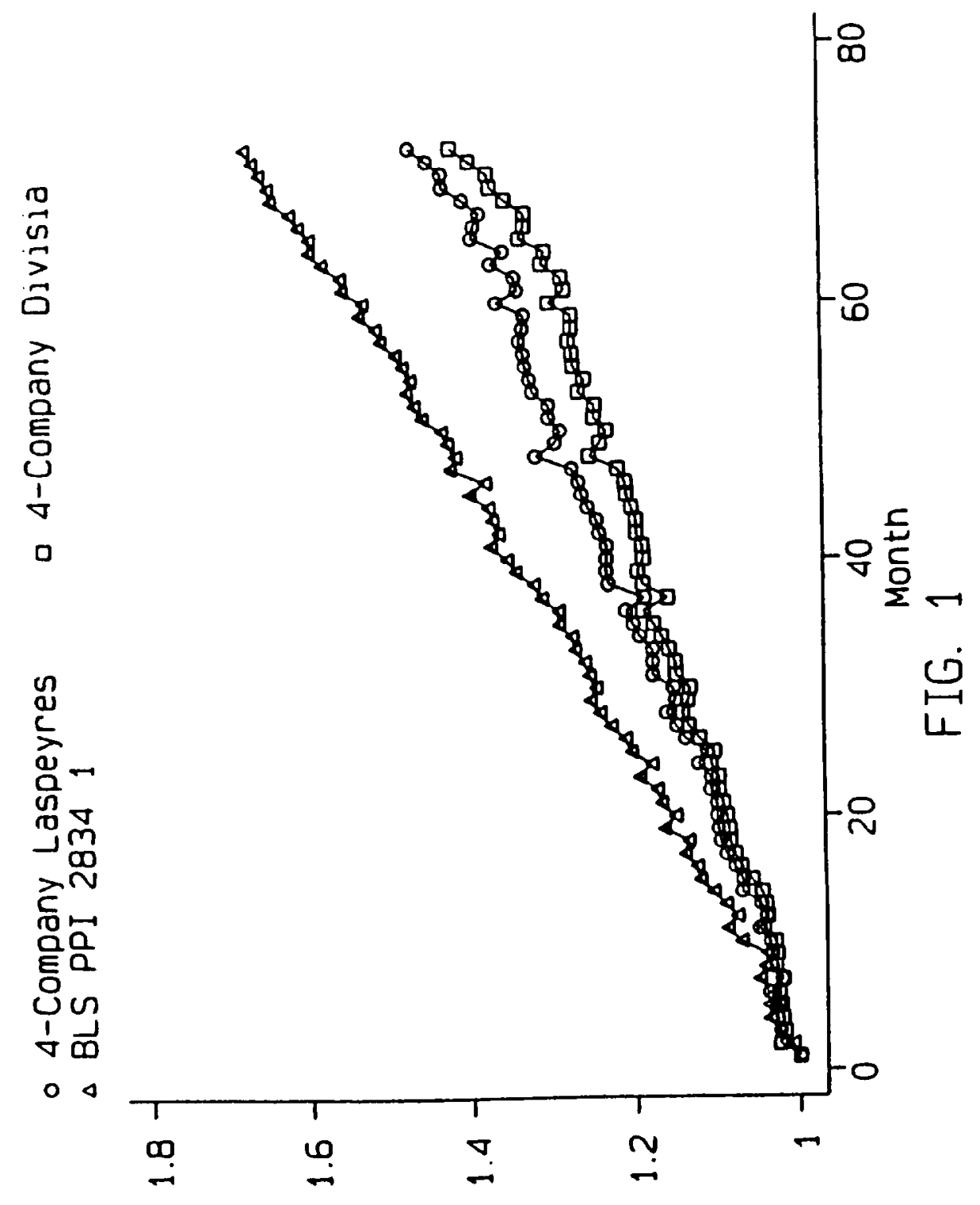


partlcipation by firms in providing BLS price data is voluntary. Also, sampling procedures used by the BLS alght not capture adequately the price trends of new products, particularly In Industries charecterlzed by rapid technological change. Thlrd, the prices reported by the flras to the BLS might differ from the flras' actual average transactions prices. 4 Fourth, use of fixed welght price Indexes such as the Lapeyres wight result in rather different growth rates fron those based on chalned procedures such as the Divisia Index. Note that one would not expect unmeasured quality changes to account for the difference, since none of the three Indexes reported above connects generlcs to their patented antecedents. nor does any compare "Improved" drugs to their predecessors and adjust the price Index accordingly using. for example, hedonic methods.

Our Interest in the rellability of offlcial producer price indexes stems from a more general research interest in the measurement of output and productivity growth. Given the essential Identlty between value of sales and a price Index times a quantity Index, any errors in the PPI have Important Implications for the accuracy of measured rates of Inflation, real output changes, real Investment, and growth In productivity.

To begin assessing the rellability of the PPI, we decided to audit one Industry in detall. Our cholce of the pharmaceutical preparations Industry was affected by the fact that this industry is one In which technological change is signiflcant, Its pricing of products has been the focus of considerable public attention. 1t has other atcributes of Interest to us (for example. It is heavily engaged in research and development), and, on a practical basis, arrangements could be made to have proprletary mlcro data made avallable for analysis. It is worth noting that our analysis is confined to the PPI for this industry, and we do not examine issues Involving the Consumer Price Index (CPI), for which a sample of prescription pharmaceutical prices drawn at the retall and hospltal 
AUDITING THE PRODUCER PRICE INDEX

levels would be required. However, some of the important issues Involving the treatwent of generles and new goods may be similar for the PPI and CPI.

We start our paper In Section II with a brlef overview of the PPI; a more decalled discussion is found In Appendix a to this paper. 5 In Section III we provide a summary of the four anonymous pharmaceutical manufacturars, comment on another source of data (IMS Anerlca) that, for one Igniflcant sub-class of pharmaceutical preparations (systemic anti-infectives), encompasses alnost the entire unlverse of products sold domestically, and present some prelininary empirical flndings Involving data coaparisons. The principal reaulte of our empirical analysis are presented In Section IV, and there we report on our varlous attempts to unravel chls mystery. In Section $V$ we address the "youthful goods" problew in further detall. Finally, In Section VI we sumarize our findings and describe our agenda for further research.

\section{THE BLS PRODUCER PRICE INDEX FOR SIC 28341}

The PPI is one of the oldest continuous stetistical data aysens published by the BLS, although unt1l 1978 it was known as the Wholesale Price Index (UPI). The flrst WPI, published for the base parlod 1890-1899, was an unwelghted average of price relatives for about 250 comodities. Since that tae, any changes have been made, Including alterations in the sanple of comodities, the base perlod, and the method of calculating the Index. According to the U.S. Department of Labor [1988, P. 125], the 1978 name change fron UPI to PPI "...was intended to reemphasize that the Industrial price progran continues to be based on prices recelved by producers from whoever makes the flrst purchase, rather than on prices paid to wholesalers by retallers or others further removed in the distribution chain." Currently the PPI progran at Bls encompasses the construction of agregate price indexes for almost 500 mining and manufacturing Industrles, Including approximataly 8,000 Indexes for specifle product 
AUDITING THE PRODUCER PRICE INDEX

categories, based on reports from approximately 23,000 responding companies.

The BLS computes and publishes an overall price Index for pharaaceutical

proparations (Standard Industrial Classiflcation [SIC] code 2834), for

prescrlption pharmaceuticals (SIC 28341), and for roughly so sub-groups from the

even to nine-diglt SIC level; a complote list of product classes reported by the BLS In SIC 28341 is given In Table 1 below. 6

Table 1

Industries in SIC 28341 for which the aLS Publishes Monthly Prlce Indexes 1984-89

\begin{tabular}{|c|c|c|c|}
\hline Induatey & sIC Code & nduatry (continued) & SIC Code \\
\hline 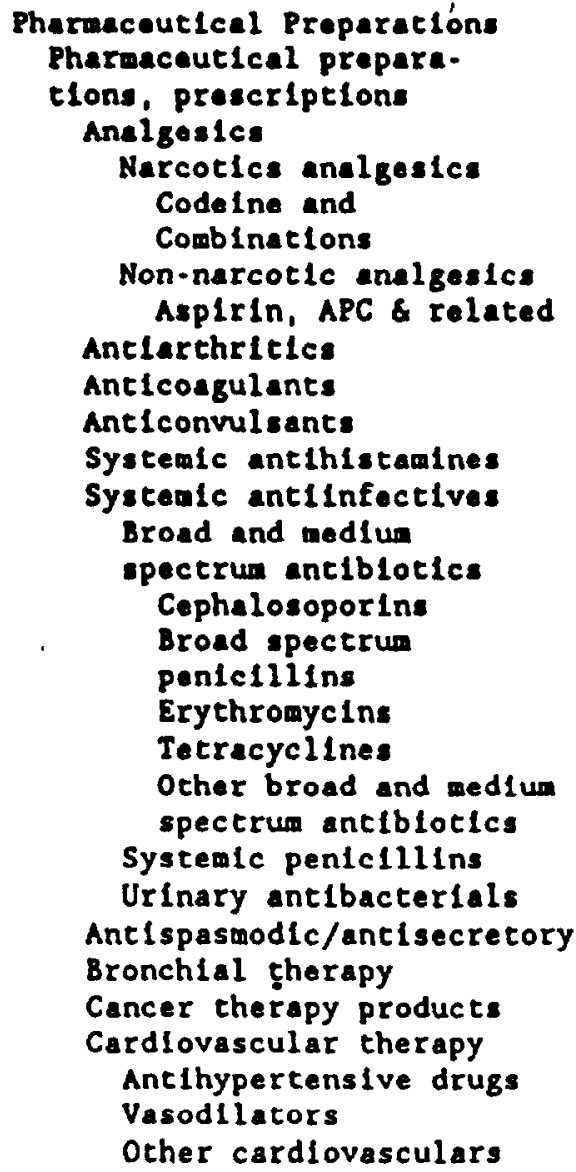 & $\begin{array}{ll}2834 & 1 \\
2834 & 102 \\
2834 & 1021 \\
& \\
2834 & 10211 \\
2834 & 1022 \\
2834 & 10229 \\
2834 & 105 \\
2834 & 106 \\
2834 & 107 \\
2834 & 109 \\
2834 & 111 \\
& \\
2834 & 1111 \\
2834 & 11111 \\
& \\
2834 & 11112 \\
2834 & 11113 \\
2834 & 11114 \\
& \\
2834 & 11119 \\
2834 & 11129 \\
2834 & 11139 \\
2834 & 116 \\
2834 & 118 \\
2834 & 119 \\
2834 & 121 \\
2834 & 12119 \\
2834 & 12129 \\
2834 & 12191\end{array}$ & 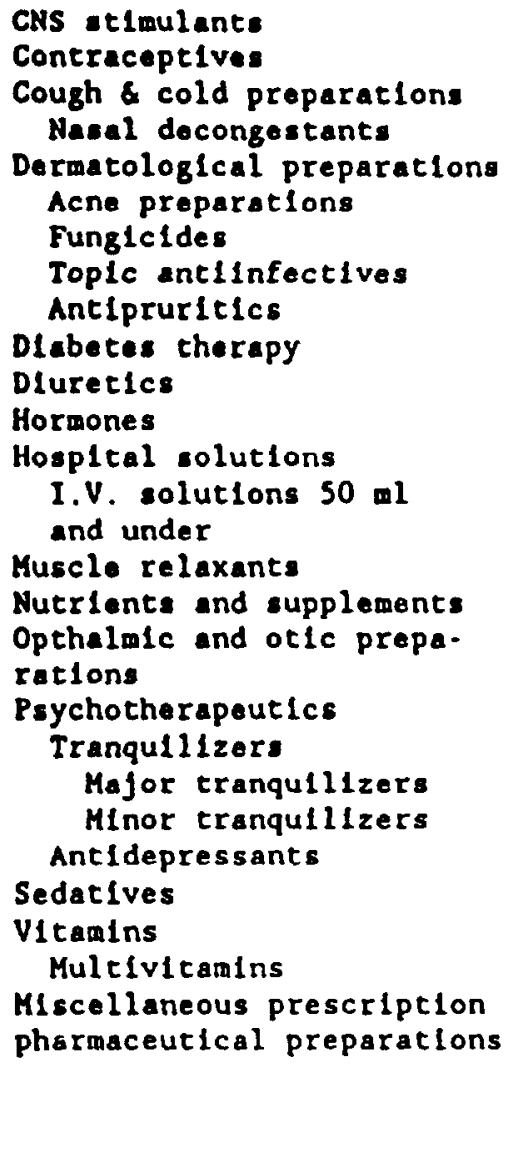 & $\begin{array}{ll}2834 & 123 \\
2834 & 124 \\
2834 & 125 \\
2834 & 12512 \\
2834 & 126 \\
2834 & 12611 \\
2834 & 12619 \\
2834 & 12631 \\
2834 & 12641 \\
2834 & 127 \\
2834 & 128 \\
2834 & 135 \\
2834 & 136 \\
& \\
2834 & 13604 \\
2834 & 139 \\
2834 & 141 \\
& \\
2834 & 142 \\
2834 & 144 \\
2834 & 1441 \\
2834 & 14411 \\
2834 & 14412 \\
2834 & 1442 \\
2834 & 145 \\
2834 & 148 \\
2834 & 14819 \\
& \\
2834 & 198\end{array}$ \\
\hline
\end{tabular}


AUDITING THE PRODUCER PRICE INDEX

The PPI for the varlous pharamaceutlal products are based on prices for a fixed basket of products, drawn frow monthly voluntary reporting to the BLS by selected manufacturing establishments. Several polnts are worth notlng.

Flrst, the fixed basket of products is chosen through a sampling procedure Implemented at Irregular Intervals acrose Industries, whose frequency depends in part on the percelved stabllity of the Industry. Detalled surveys of pharmaceutical firms were conducted In 1980 and In 1987, and the flxed baskets were changed In 1981 and in January 1988; the BLS refers to the 1980 survey as "Cycle I", and that from 1987 as "Cycle II".

Second, In principle, the sample is drawn from the universe of all products from domestic establishments whose main production is in SIC $2834.7 A$ BLS field representative visits selected establishments (In the pharmaceutical Industry, the BLS vislts wherever the approprlate records are kept, usually company headquarters) during the survey year, and uses a procedure called "disaggregation" to settle on whlch detalled products are to be sanpled. Once this initial visit is completed, subsequent "repricing" for the selected commodItles occurs on a monthly basis, cyplcally by the respondent company filling out and returning forms sent it by mall by the BLS; these forms are pre-printed with the detailed description of the chosen products, the reported prices over the prevlous three or four months, and a request for price quote fron the Tuesday of the week contalning the 13 th of the month. Currently, approximately 50 responding companies in SIC 28341 provide about 400 individual price quotations. Third, once monthly data are In hand, the BLS calculates the PPI according to a modified Laspeyres fornula, detalls of which are given in Appendix $A$.

Fourth, during the disaggregation process, products are defined in very specifle detall. As the U. S. Department of Labor (1986a, 1989) nanuals emphasize, any price-deteraining characterlstic distingulshes one product from 
AUDITING THE PRODUCER PRICE INDEX

another. The U. S. Departaent of Labor [1988, p. 126] sumber1zes price-

deteraining characteristics as follows:

"If a company charges more for a red widget than a white one. color 1s one of the price-determining variables; if all widgets sell for the sane price regardless of color, color is not a price-determining variable."

In the pharnaceutical context, If prices of bottles differ, a bottle of 100 plils each having 50 milligrams of a drug is not the same as a bottlo of 50 p111. of 100 allligrans, even though both bottles contain 5,000 milligrams of the same drug. Horeover, transaction-specific factors such as volume discount: or trelght costs (1f absorbed by the nanufacturer) affect price, so these factors are included in the definition of the product.

Stxth, precisely how the BLS deternines the total number of price quotations assigned to each establishment is not completely clear, but apparently this decision Involves substantial judgment. According to the US Departaent of Labor [1986b, PP. 42-46], the number of quotes taken from an establishent depends on Industry concentration, price variations within and across establishments, establishment size, and the number of products produced at each escablishment. Moreover, discusstons with BLS personnel suggest that for any sampled establishment In any Industry, there is a minimum of two quotes and a maximum of sixteen. In recent years, the number of compantes sanpled has declined within the pharmaceutical industry, there has been an effort to Increase quotes to large sample units and to distribute quotes across product IInes to create more efficlent index estimates. Hence, In practice the cholce of products sampled departs ignificantly from strict probabllity sampling procedures.

Finally, although the BLS manuals emphasize that transactions rather than 11st prlces are desired, and Form 473 s states clearly that "net transactions prices are the most desirable type of price," the BLS also accepts net 11 st 
AUDITING THE PRODUCER PRICE INDEX

prices (with additional pricing terms listed separetely, such as discounts for prompt payment), or other estlmates of prices. Desplte the BLS emphasis on transactions prices, our discusstons with personnel et various pharmaceutical flrms suggest that firms typlcally interpret this request as belng one for net list rather than net transactions prices.

For our purposes it is important to note that once detalled products have been chosen by the disaggregation process, the BLS obtains a time-series of prices for highly defined products which stays constant over falrly long incervals - Indeed, the six years between re-sampling suggests that the set of sampled commodities is dominated by mature, rather than Innovative products.

As was noted earlier, the mose recent detalled survey in pharmaceuticals occurred in mid-1987, and beginning in December 1987, the PPI was revised to reflect the new sample of products, withln-cell wolghts, and between-cell welghts from the 1982 Census of Manufacturers. Currently, PPI's for pharmaceutical products are based at 100 in June 1981.

Although in principle the PPI has been based on probability sampling since late 1978, In practlce it is clear that a number of departures from ideal establishment selection and disaggregation occur. In addition to the judgmental manner in which the number of price quotes per establishnent is deternined, the voluntary nature of the PPI Introduces problems for BLS field representatives. Moreover, the U. S. Department of Labor [2986a,1989] data collection manuals provide extensive advice to BLS fleld representatives when the establishment employee Interviewed by BLS personnel aay not have or any refuse to provide sufficlent Information for complete disaggregation. Of course, the Iaplications of such departures of practice from theory are not clear. 


\section{DATA SETS USED IN THIS STUPY AND INITIAL EMPIBICAL FINDINGS}

He now sove on to a discussion of the varlous data sets used In our anelysis. Confidential data have been provided us by four of the ten largest firss in the industry, together comprising about $24 x$ of domestic sales in 1989. For aach of the 2,090 preserlpeton pharmaceutlcal products produced by these four coapanles, we have been supplled monthly data from January 1984 through December 1989 (72 monthly observatlons) on net revenues, quantity shipped, net revenue/quentity, and product ldentlflers. Net revenues are close to accrual besis, Implylng that the computed average transactions prices are close to the erue quantity-weighted average prices for seles in the given month. However, it 18 worth noting that such everage transactions prices could in principle be affectad by the size and location of transactions, and that no information is ava1lable to us on whether such features of transactions have changed over time. The product Identiflers allow unchanged producte (down to the presentation level) to be followed over tine, since presentation characteristics such es form (vial, capsule), dosage, package size (count) and type (bottle, blister pack) are known.

Since none of the companies had complete records of forms it had filled out for the BLS, In response to written requests from the Individusl companies, the BLS provided a computer data flle to each company containing records of price quotes reported by that company to the BLS from January 1984 through December 1989. The companles then supplled these flles to us. The sample frame items selected by the BLS represented roughly 10-11x of the four companles' total revenues in both cycles.

Additional product detalls were provided us by each company, and these were used to classify products into therapeutic classes as defined by the BLS. of the 2.551 products supplled overall, we succeeded In classifying 81.92 of 
them into speciflc BLS prescription cell groups (see Table 1 for a 1 ist of these cells); these successfully classifled products accounted for wore than $98 \mathrm{x}$ of revenues over the sample perlod. 8 In this paper, when we present price index data, we refer to calculations based on the 2,090 classifled prescription products only.

New products are of particular interest, for they may embody technologlcal Innovations which allow therapeutic actions for which there is no known price, and the speed with which these new products are Introduced into price Index calculations can substantially affect the measured overall rate of price growth. Many of the new products in the companies' data sets are actually modiflcations of exlsting product lines (new packaging, etc.), but other products are truly new In the sense of belng the first presentation of a newly approved drug. We have also examined products that exit. The extremely small revenue share of exiting products makes it improbable for them to have a subsantial inpact on aggregate measures of price, and therefore wo do not explore exits in detall in this study.

It is of course quite possible that, within therapeutic classes, our 4company sample of firms is unrepresentative of the Industry as a whole. To assess this issue for one Important class of drugs, we have obtalned monthly price and revenue data on almost the entire unlverse of products withln syetealc anti-Infectlves (SIC 2834-111), a sub-class accounting for approxidately $16 x$ of SIC 28341 domestic total sales in 1987 . The data vere purchased from IMS America. 9 The number of products for which IHS monthly price data is avallable Is 5,545, but the IMS time perlod differs slightly from that for our foux companles - from October 1984 rather than January 1984 to December 1989.

There are several other lmportant differences between the company-specific and IMS data. 10 While the data underlying the PPI are those on prices recelved by producers from whomever wakes the first purchase, the IMS data cover 
transectione at a different point in the distribution chain. Spoclfically, the IMS date represent the purcheses made by hospltale and by retallers of ethical, ethlcal over-the-counter, and proprletary pharmaceutical products. IMS estimates that Its drugetore audit covers $67 \%$ of the US pharmaceutical market, and that Ita hospltal audit covers an additlonal $16 \%$. The market segments that the two audits do not monitor include foodstores, dispensing physiclans, HMO's, mall order nursing homes, and clintes.

The purchase Information obtained by IHS from a panel of hospltal and a sample of wholesale warehouses for 1 ts hospltal audit is projected by IMS to natlonal (continental US) levels, not Including foderal hospitals or nursing homes. Based on involce data, the prlces reflect the actual costs of products to hospltals, whether purchesed from anufacturer or a wholesaler.11

In the retall deta set, Involce-based price data raflect the actual cost to retallers for the ethical, ethical over-the-counter and proprletary pharmaceutical products, whecher purchased from a manufacturer or wholesaler (IMS notes that 928 of total pharmaceuticals purchased by retall outlets are from wholesalers). For both the hospital and retall data, IMS cautions that prompt payment cash discounts (usually 24 off) and bottomline involce discount: are not reflected in the dollar purchase amounts.

\section{PRICE INDEXES DISAGGREGATED BY PRODUCT CLASS}

Because the PPI and IMS data are taken from different polnts in the distribution chaln, the prlces (unlt costs) In the IMS data reflect markups over the prices reported by producers to the BLS. These markups could vary over tfme. or be trended. To check on the posslbillty that IMS prices grow differently frow producer prices, we have compared prices for 241 exact product matches between IMS and the four-company data. 12 Speciflcally, for each of these 241 products, we have taken the ratlo of the IMS unit cost to the company's average revenue, monthly from October 1984 through December 1990. We 
AUDITING THE PRODUCER PRICE INDEX

then computed a Divisia Index of this ratio, using company revenue welghts. If the warkups were constant over time, growth of this Divisle index would be zero. Over the October 1984 -December 1990 time perlod, thls Index grew frod 1.000 to 1.041, an average annual growth rate (AAGR) of $0.77 x$, Implying that IMS prices grew slightly wore than company-speciflc average revenues for these 241 products. 13 We Interpret this result as implying that even though IMS and PPI prices are drawn from different points in the distribution chaln, on average their price changes are slallar over the sample time perlod. This simllarity in overall growth rates of the IMS and company-provided data also glves us some confidence in using the IMS data as a proxy for producer price level price index calculations. 14

Using this IMS data, we have computed alternative prlce Indexes for the systemic anti-Infectives sub-class (recall that the IMS data encompass almost che universe of products sold domestically). Our results ar sumarized in Figure 2. Over the October 1984 through December 1989 time perlod, while the [Insert Figure 2 somewhere near hera] officlal BLS PPI for systemic antl-Infectives increased at an MAR of 6.26\%, the IMS Laspeyres fixed-weight index grew at 2.63\%, and the IMS Divisia Index with new goods Included Immediately grew at only $1.54 x$. one fourth the growth rate of the officlal PPI. 15 Hence, there is Indeed a mystery here, for when data are taken from a product class with alwost universal coverage, the offleilal PPI and the IMS-based Laspeyres and DIvisla Indexes grow at very different rates. Hence It appears that our Initial findings based on all products from but four firas are corroborated using the unlverse of products for the systemic anti-infective subclass.

Some other evidence can shed 1 ight on the representativeness of our fourcompany sample and, In partlcular on the possibility that product mix differentials along with variations in price growth by product sub-class could 
Index Value

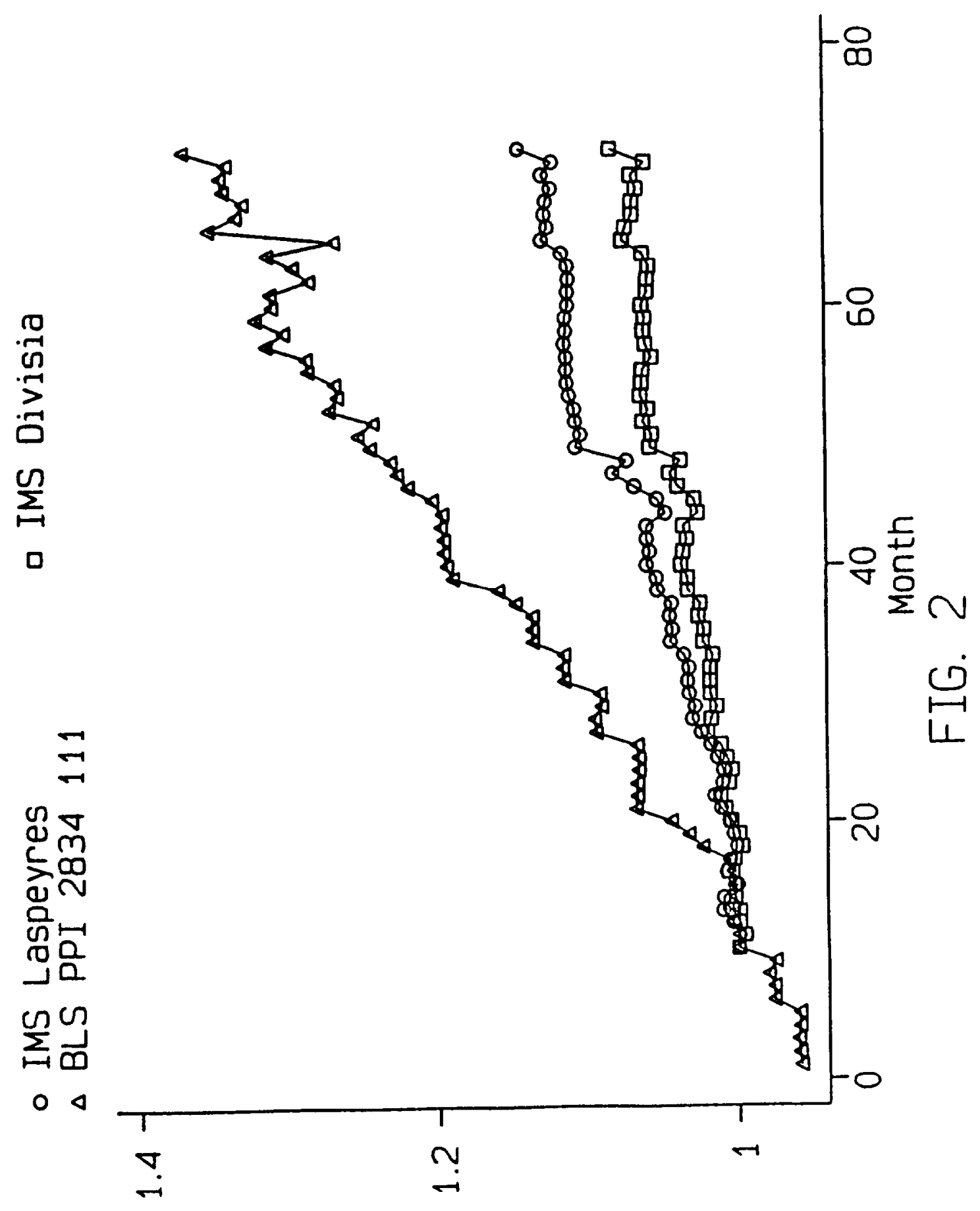


Table 2

FOUR COMPANY AND INDUSTRY DATA

\begin{tabular}{|c|c|c|c|c|c|c|}
\hline \multirow[b]{2}{*}{ Product Class Name } & \multirow{2}{*}{$\begin{array}{l}\text { Product } \\
\text { Class } \\
\text { Number }\end{array}$} & \multicolumn{2}{|c|}{$\begin{array}{l}\text { Product Share } \\
\text { Distribution }\end{array}$} & \multicolumn{2}{|c|}{$\begin{array}{c}\text { Census - BLS } \\
\text { Relative } \\
\text { Helghts }\end{array}$} & \multirow{2}{*}{$\begin{array}{r}\text { Approximate } \\
\text { Four-Company } \\
\text { Concentration } \\
\text { Ratle } 1982\end{array}$} \\
\hline & & $\begin{array}{c}\text { 4-Company } \\
1987\end{array}$ & $\begin{array}{l}\text { IMS-A11 } \\
1987\end{array}$ & $\begin{array}{r}\text { Hel } \\
1977 \\
\end{array}$ & & \\
\hline Analgesics & 102 & $3.59 x$ & $7.22 x$ & $5.21 x$ & $9.82 x$ & $12.01 x$ \\
\hline nel-arthrites & 105 & 13.36 & 6.21 & 3.41 & 4.83 & 51.92 \\
\hline nel-coagulanes & 106 & 0.14 & 0.59 & 0.51 & 0.68 & 5.84 \\
\hline $\begin{array}{l}\text { Systemlc Antl-Infectives } \\
\text { Antl-spasmodic/ }\end{array}$ & 111 & 26.46 & 15.59 & 14.23 & 15.28 & 40.99 \\
\hline Antl-secretory & 116 & 1.30 & 7.46 & 1.70 & 1.01 & 4.21 \\
\hline $\begin{array}{l}\text { Cancer therapy } \\
\text { Cardlovascular } \\
\text { Cough \& Cold Preparations } \\
\text { Dermatologlcal }\end{array}$ & $\begin{array}{l}119 \\
121 \\
125\end{array}$ & $\begin{array}{r}0.65 \\
17.44 \\
0.02\end{array}$ & $\begin{array}{r}2.94 \\
19.60 \\
1.67\end{array}$ & $\begin{array}{r}1.12 \\
10.26 \\
2.04\end{array}$ & $\begin{array}{r}3.77 \\
15.64 \\
3.60\end{array}$ & $\begin{array}{r}5.32 \\
21.49 \\
0.32\end{array}$ \\
\hline $\begin{array}{c}\text { Preparations } \\
\text { DLabetes Therapy }\end{array}$ & $\begin{array}{l}126 \\
127\end{array}$ & $\begin{array}{l}0.56 \\
9.34\end{array}$ & $\begin{array}{l}3.48 \\
2.89\end{array}$ & $\begin{array}{l}2.60 \\
2.49\end{array}$ & $\begin{array}{l}3.37 \\
1.97\end{array}$ & $\begin{array}{r}3.86 \\
78.08\end{array}$ \\
\hline $\begin{array}{l}\text { Hormones } \\
\text { Muscle Relaxants } \\
\text { Nutrlents \& Supplements } \\
\text { Psychotherapeutics } \\
\text { Sedatlves }\end{array}$ & $\begin{array}{l}135 \\
139 \\
141 \\
144 \\
145\end{array}$ & $\begin{array}{l}2.56 \\
1.83 \\
0.08 \\
9.05 \\
2.76\end{array}$ & $\begin{array}{l}4.50 \\
1.79 \\
2.30 \\
8.27 \\
1.10\end{array}$ & $\begin{array}{r}10.92 \\
1.71 \\
0.23 \\
10.95 \\
1.18\end{array}$ & $\begin{array}{l}3.78 \\
0.86 \\
0.24 \\
7.57 \\
0.80\end{array}$ & $\begin{array}{r}13.75 \\
24.66 \\
0.81 \\
26.43 \\
60.91\end{array}$ \\
\hline All Others & & 10.86 & 14.39 & 31.44 & 26.78 & \\
\hline TOTAL & & 100.00 & 100.00 & 100.00 & 100.00 & 24.16 \\
\hline $\begin{array}{l}\text { Notes: The } 4 \text {-company pro } \\
\text { companles by product clas } \\
\text { prescription classlfied } \\
\text { assignments less unassign } \\
\text { total Industry revenues b } \\
\text { across all flrms in the I } \\
\text { of shipments net of Intra } \\
1982 \text { Census. The } 4 \text {-compa } \\
\text { revenues for the four fir } \\
\text { estimated total Industry } \\
\text { wholesaler markups, this } \\
\text { true ratlo. }\end{array}$ & $\begin{array}{l}\text { ss, divid } \\
\text { revenues } \\
\text { ned reven } \\
\text { by produc } \\
\text { Industry. } \\
\text { a Industry } \\
\text { any conce } \\
\text { ros in th } \\
\text { revenues } \\
4 \text {-compar }\end{array}$ & $\begin{array}{l}\text { ed by the } \\
\text { (total } 198 \\
\text { ues). The } \\
\text { class di } \\
\text { The Cens } \\
\text { sales by } \\
\text { ntration } \\
\text { is study b } \\
\text { by produc }\end{array}$ & $\begin{array}{l}\text { sum of th } \\
7 \text { revenue } \\
\text { IHS-All } \\
\text { vided by } \\
\text { us-BLS we } \\
\text { product } \\
\text { at lo is c } \\
\text { y product } \\
\text { class. }\end{array}$ & $\begin{array}{l}\text { four } \\
\text { less n } \\
\text { product } \\
\text { the } \\
\text { lghts } \\
\text { lass, b } \\
\text { ompany- } \\
\text { class, } \\
\text { SInce }\end{array}$ & $\begin{array}{l}\text { companie } \\
\text { on-presc } \\
\text { share } \\
\text { of tots } \\
\text { re the } \\
\text { ased on } \\
\text { provided } \\
\text { divided } \\
\text { the IMS }\end{array}$ & $\begin{array}{l}\text { for the four } \\
\text { es' total } \\
\text { cription } \\
\text { distribution to } \\
\text { al revenues } \\
\text { relative value } \\
\text { the } 1977 \text { and } \\
\text { d data on total } \\
\text { d by IHs } \\
\text { deta include } \\
\text { derstates the }\end{array}$ \\
\hline
\end{tabular}


AUDITING THE PRODUCER PRICE INDEX

account for differences in four-company price growth ve. that of the official

PPI. Based on revenue data from the four-company ample, we have computed product revenue share data by product class, and compared these to Industry-wide product diseribution data estimated by IMS. 16 The two sets of product

distribution shares are given in Table 2 . There it is seon that product distribuction shares differ somewhat between our four-company sample and the IHS "universe".

We have also obtained Census Bureau data on rovenues by product class based on the 1977 and 1982 Census of Manufactures. As 1s seen In Table 2, the 1982 Census-BLS welghts axe broadly consistent with the product share data reported by IMS for 1987 . Although by 1987 the welghte of anti-spasmodic/ant1secretory, cardlovascular, and nutrients supplements were larger than in 1982 , while that for analgesics was somewhat saller.

In Table 3, we report MGR of the published PPI, the four-company Laspeyres, and the four-company DIvisia Index, by product class, over the 1/84. 12/89 time perlod. The Laspeyres Index minlcks the BLS fixed weight with splice computational procedures, whereas the Dlvisia index Includes new goods Immedlately and employs smoothed four-month moving average share wolghts. 17 As Is seen In Table 3, In most cases the PPI growth 1s larger than that for the four-company DIvisla (especially for cancer therapy products, dermatological preparations, and sedatives), but in some cases the PPI grows less rapidly than the four-company DIvisia (for example, in antl-arthritics, and especially in muscle relaxants). We conclude, therefore, that whlle on average the PPI for pharmaceutical preparaclons grows considerably wore rapldly then the fourcompany Divisla ( $9.09 x$ vs. 6.03x), there is considerable diversity across subclasses and in some cases the Inequality is reversed. 
Table 3

GROUTH IN ALTERNATIVE PRICE INDEXES BY DISAGGREGATED PRODUCT CLASS

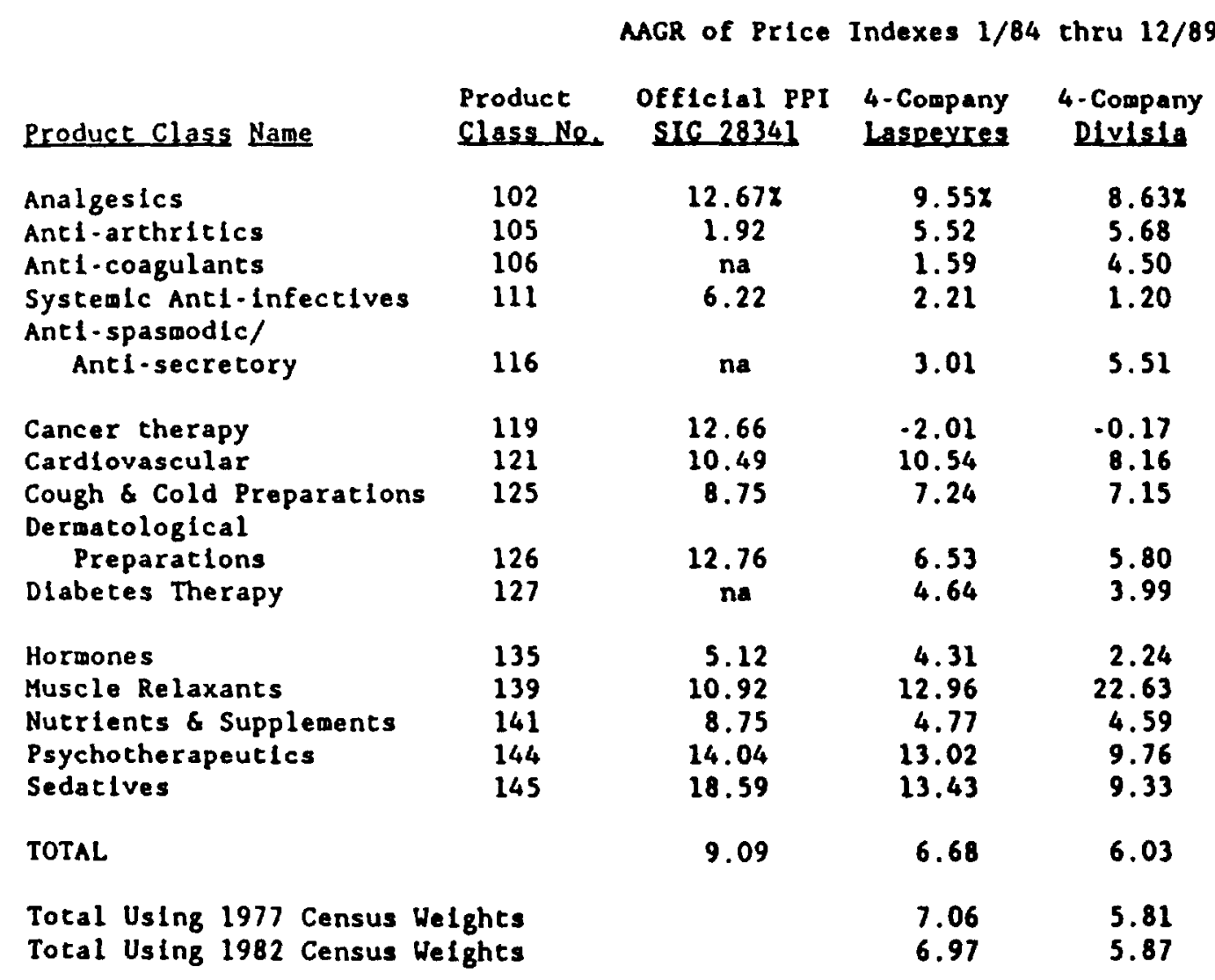

Note: na Implies that the PPI for this industry is not published, due to an insufflcient number of reportings to the BLS.

As another check on the persistence of our mystery and the representative. ness of our four-firm sample, we have used Item-specific weights to compute MGR by Industry sub-class (see the last two columns of Table 3), but have then constructed an overall price Index welghting these sub-classes using the BLS. Census welghts from Table 2, racher than the four-company weights. If the revenue distribution across product classes in our four companies were sufficlently different from the BLS-Census welghts, then the MAGR for SIC 28341 
AUDITING THE PRODUCER PRICE INDEX

In total could differ depending on what welghts were employed. As is seen in the last three rows of Table 3 , however, this is not the case. Using four. company sub-class welghts, we see that the MAR of the Laspoyres Index $186.68 x$, wh1le those based on the 1977 and 1982 Census welghts are $7.06 x$ and $6.97 x$. respectively; for the DIvisia index, the four-company weights yield an MaGR of 6.03\%, whlle use of the 1977 or 1982 Census volghts generetes MAG's of $5.81 \mathrm{x}$ and 5.87x. Since these differences are inar compared to the much larger AMGR of the officlal PPI (9.09x), we conclude that varlations in revenue product cless welghts between our four companles and the Industry overall cannot account for the discrepancy between growth of the officlal PPI and varlous price Indexes based on our four-company data.

\section{III.b REPORTED VS. ACTUAL AVERAGE TRANSACTIONS PRICES}

As another aspect of our data, we have compared prices reported to the BLS by the four companies with average transactions prices recelved by the company. For the 25 products sampled in Cycle I and for the 46 Items sampled in Cycle II from the four companies ( 7 are retalned from Cycle I to Cycle II, leaving a total of 64 products) the Laspeyres Index of prices reported to the BLS Increased at an AAGR of $8.94 \pi$, while average transactions prices Increased at $9.52 x$ per year. 18 Thus the $8.94 \times$ AAGR of prices reported to the BLS by our four companles is almost Identical to the 9.097 AAGR of the PPI, suggesting that in terms of price growth for sampled items, our four companies are essentially representative of the Industry as a whole.

We have also compared reported prices and average transactions prices for the sampled items in the systemic anti-infectives product sub-class. Over the entire 1/84-12/89 time span the two Laspeyres Indexes grew at virtually Ldentical rates - $8.60 x$ for transactions prices, and 8.534 for reported prices, 
AUDITING THE PRODUCER PRICE INDEX

both of which are conslderably larger than the offlclal PPI which grew at an

AACR of $6.22 \times .19$

Reported and average transactlons prices can also be compared in terms of levels rather than growth rates. For the same four-company sample, the unwelghted average of the ratlo of reported to average transaction price was 1.090. while a corresponding revenue-welghted ratio is 1.032 ; it is worth noting, however, that these ratios display considerable varlabllity.

\section{SOME CLUES AND AN IMPORTANT EINDING}

Our analysis to this point suggests that the products sampled by the BLS In this Industry appear to have price trends that differ frou representative eransactions for the four companies in our sample, and in the systemic ant1Infective sub-class, from essentially the Industry as whole. What is it about the BLS sampling procedures that on average appear to miss the smaller price increases of representative transactlons?

Since the potentlal existence of "new goods" problem has been known for quite some time, 20 we began our search for an explanation by simply looking at the mean age of products sampled by the BLS relative to the average age of all dated products in the four companies. 21 This coarse analysis turned out to be uninformative, since differences were small.

Another line we pursued, following a conjecture presented in Berndt. Grlliches and Rosett [1990], Involved examining the extent to which Itens sampled by the BLS in Cycle I were re-sampled by then in Cycle II. For the 25 ltems in the four companies sampled by the BLS In Cycle I, seven were re-sampled In Cycle II. Whether such a $28 \mathrm{x}$ re-sampling rate is consistent with probability sampling procedures is not clear, but it appears unlikely to us that this amount of re-sampling could be responsible for the BLS sample falling to plck up adequately the smaller price increases of representative transactions. 
AUDITING THE PRODUCER PRICE INDEX

- Page 17 .

We then examined the role of new products in a different manner. conjecturing that while the distribution of products by age may en average be roughly inllar for the BLS sampled 1tems and the four-company aggregate, they ight be skewed in different ways. To follow this up, we first defined six age groups (less than two years old, between 2 and 3.999 years, 4 and 6.999 years, 7 and 9.999 years, 10 and 24.999 years, and 25 or more years old). We then divide age group specific revenues of BLS sampled Items in the four companies by total annual revenues for all BLS sampled items at the four companies. Simflarly, four-company age-speclfic revenue shares were defined as the aggregate annual age-group specific revenues for the four companles divided by total annual revenues for the four companies. As is seen in Table 4, the results of these calculations begin to provide Important clues to help unravel our mystery.

\section{Table 4}

Annual Revenue Shares by Age of Product for Items at the Four Companles Sampled by the BLS, and for All Products at the Four Companies

CYCLE I TIME PERIOD

\begin{tabular}{|c|c|c|c|c|c|c|c|c|c|}
\hline Age & In Xears & $\begin{array}{c}\text { Unlverse } \\
1984\end{array}$ & $\begin{array}{c}\text { Sample } \\
1984\end{array}$ & $\begin{array}{c}\text { Unlverse } \\
1987\end{array}$ & $\begin{array}{c}\text { Sample } \\
1987\end{array}$ & $\begin{array}{c}\text { Universe } \\
1988\end{array}$ & $\begin{array}{c}\text { Sample } \\
1988\end{array}$ & $\begin{array}{c}\text { Universe } \\
1989\end{array}$ & $\begin{array}{c}\text { Sample } \\
1989\end{array}$ \\
\hline 0 & -1.999 & $20.78 x$ & $0.00 x$ & $32.57 x$ & $0.00 x$ & $21.85 x$ & $8.58 x$ & $28.29 \%$ & $7.32 x$ \\
\hline 2 & -3.999 & 16.70 & 8.96 & 14.81 & 9.08 & 8.62 & 4.02 & 7.16 & 3.28 \\
\hline 4 & -6.999 & 17.40 & 13.13 & 20.94 & 29.99 & 29.13 & 33.20 & $2 B .11$ & 33.39 \\
\hline 7 & -9.999 & 11.73 & 30.24 & 10.01 & 28.72 & 18.79 & 39.19 & 19.14 & 44.56 \\
\hline 10 & - 24.999 & 23.43 & 45.18 & 15.92 & 30.21 & 16.92 & 13.32 & 13.43 & 10.05 \\
\hline 25 & or more & 9.96 & 2.50 & 5.75 & 2.00 & 4.69 & 1.69 & 3.87 & 1.41 \\
\hline & TOTAL & 100.00 & 100.01 & 100.00 & 100.00 & 100.00 & 100.00 & 100.00 & 100.01 \\
\hline
\end{tabular}

Notes: The age In years for Cycle I is as of January 1, 1984, and that for Cycle II is January 1.1988. Totals may not sum to $100 \%$ due to rounding. 
AUDITING THE PRODUCER PRICE INDEX

In 1984 and 1987, while Items under two years of age were not sampled at all by the BLS (recall that the Cycle I survey occured In June 1981), products less than two years comprised about $21 \%$ (1984) to $33 \%$ (1987) of total sales at the four companies; products between two and four years old comprised about $17 x$ (1984) or 157 (1987) of company total sales, while BLS sampled items within thls age group consticuted about $9 x$ of revenues in both 1984 and 1987 . Altogether for both age groups, shares of BLS sampled products under four years of age generated only $9 x$ of revenues, whlle at the four companles these products constlcuted between $38 x$ (1984) and $47 x$ (1987) of total sales. Hence, younger products appear to be undersampled by the BLS.

Relaclve to company-wide shares, during both cycles the BLS over-sampled mediun-aged products, especlally in the 7-10 age group. For example, as Is seen In Table 4, BLS sampled products between 7 and 10 years of age accounted for about 307 of 1984 BLS Item revenues, but this age group generated only $12 \pi$ of total company revenues: In 1989, the corresponding shares are $45 x$ and $19 x$.

Recall that earller we reported that sales-welghted mean ages for BLS sampled ltems and the universe of the four-company items were very sinllar. In this concext. It is worth noting that the age distribution of products sampled by the BLS tends to be wuch more concentrated than is that for all products at the four compantes. In 1989, for example, products between ages 4 and 10 comprised about $78 \%$ of BLS sampled Iten revenues, yet only accounted for about $47 x$ of four-company revenues.

While these substantial differences in shares by age group are striklng, they would not contribute at all to unravelling our mystery were it the case that product price changes by age group are similar. If, however, for whatever reason, younger products that are undersampled by the BLS experience less than average price increases whlle mediun-aged, oversampled items undergo larger 
price Increases, then we would be able to understand better why the AAGR of the four-company unlverse and the PPI differ.

To check on this further, we ran a regression based on 5,761 observations frow our four-company sample. Speciflcally, we first computed an annual average cransactions price for each product as total annual revenues divided by total annual quantity. We then defined an annual prlce change dependent varlable d $\log _{\mathrm{g}} \mathrm{as}$ the logaritholc first differences of these prices. As regressors, we specifled dumay varlables for the age of the product for the $1 \times$ age classes noted above (using the age of the product as of December 31 of the latter year), company dummles, year dumnles, and SIC product class dummles. The results of this regression, with observations weighted by revenue shares 22 , are presented In Table 5. Note that the year dumbles refer to differences in the rate of change frow that occurring between 1984 and 1985; the age dummies are Interpreted as differences in the rate of prlce growth from that for the over age 25 product group.

As Is seen in Column (1) of Table 5 , relative to the over age 25 product group, Items less than two years old experience about a $3.5 \%$ smaller annual price change, while Items between 7 and 10 years old experlence about a $2.5 \%$ lerger annual price change, ceterts parlbus; the $t$-value of greater than six for each of these two coefficlents indicates strong statistical significance. Products between 2 and 4 and between 4 and 7 years old have slightly snaller price changes, but the c-values of less than one suggest that items from these age groups do not experlence statistically signiflcantly different price changes. Finally, products in the 10-25 age group (which Includes in particular patent expired products) experience about a $0.8 \%$ larger annual price change relative to over age 25 products, but the 1.779 -value implies statistical sfgniflcance only at levels less than about $92.5 \%$. 
Table 5

Results from Revenue Helghted Age-Price Regressions d log $P$ as Dependent Varlable (Absolute value of t-statistics In parenthoses)

\begin{tabular}{|c|c|c|c|c|}
\hline Repressor & (1) & $\begin{array}{r}\text { Products } \\
\text { (2) }\end{array}$ & $\begin{array}{l}\text { SIC } 28 \\
\text { (3) }\end{array}$ & $\begin{array}{l}11 \text { Only } \\
\text { (4) }\end{array}$ \\
\hline CONSTANT & $\begin{array}{l}.0427 \\
(5.45)\end{array}$ & $\begin{array}{l}.0399 \\
(4.99)\end{array}$ & $\begin{array}{c}-.0321 \\
(2.33)\end{array}$ & $\begin{array}{r}-.0376 \\
(2.74)\end{array}$ \\
\hline D1986 & $\begin{array}{l}.0122 \\
(2.53)\end{array}$ & $\begin{array}{l}.0129 \\
(2.68)\end{array}$ & $\begin{array}{c}-0003 \\
(0.02)\end{array}$ & $\begin{array}{l}.0001 \\
(0.01)\end{array}$ \\
\hline D1987 & $\begin{array}{c}-.0199 \\
(4.36)\end{array}$ & $\begin{array}{c}-.0194 \\
(4.27)\end{array}$ & $\begin{array}{l}.0017 \\
(0.12)\end{array}$ & $\begin{array}{l}.0028 \\
(0.21)\end{array}$ \\
\hline D1988 & $\begin{array}{l}.0074 \\
(1.72)\end{array}$ & $\begin{array}{l}.0050 \\
(1.17)\end{array}$ & $\begin{array}{r}-.0564 \\
(4.18)\end{array}$ & $\begin{array}{r}\cdot .0584 \\
(4.37)\end{array}$ \\
\hline D1989 & $\begin{array}{r}-.0056 \\
(1.34)\end{array}$ & $\begin{array}{c}-.0048 \\
(1.16)\end{array}$ & $\begin{array}{r}-0349 \\
(2.42)\end{array}$ & $\begin{array}{r}-.0308 \\
(2.15)\end{array}$ \\
\hline $\operatorname{ACE}(<2)$ & $\begin{array}{r}-.0347 \\
(6.19)\end{array}$ & $\begin{array}{c}-.0347 \\
(6.20)\end{array}$ & $\begin{array}{l}.0212 \\
(1.25)\end{array}$ & $\begin{array}{l}.0196 \\
(1.16)\end{array}$ \\
\hline $\operatorname{AGE}(2<4)$ & $\begin{array}{c}-.0040 \\
(0.95)\end{array}$ & $\begin{array}{r}-.0028 \\
(0.65)\end{array}$ & $\begin{array}{r}\cdot 0399 \\
(2.91)\end{array}$ & $\begin{array}{r}-.0401 \\
(2.94)\end{array}$ \\
\hline$A G E(4<7)$ & $\begin{array}{c}-.0024 \\
(0.58)\end{array}$ & $\begin{array}{c}-.0049 \\
(1.18)\end{array}$ & $\begin{array}{l}.0311 \\
(2.43)\end{array}$ & $\begin{array}{l}.0256 \\
(2.01)\end{array}$ \\
\hline $\operatorname{AGE}(7<10)$ & $\begin{array}{l}.0252 \\
(6.13)\end{array}$ & $\begin{array}{l}.0250 \\
(6.10)\end{array}$ & $\begin{array}{l}.0830 \\
(5.87)\end{array}$ & $\begin{array}{l}.0728 \\
(5.13)\end{array}$ \\
\hline$A G E(10<25)$ & $\begin{array}{l}.0082 \\
(1.78)\end{array}$ & $\begin{array}{l}.0031 \\
(0.67)\end{array}$ & $\begin{array}{l}.0844 \\
(6.24)\end{array}$ & $\begin{array}{l}.0744 \\
(5.48)\end{array}$ \\
\hline \multirow[t]{2}{*}{ BLSDUMMY } & .. & $\begin{array}{l}.0292 \\
(6.61)\end{array}$ & & $\begin{array}{l}.0560 \\
(4.66)\end{array}$ \\
\hline & $\begin{array}{r}.1632 \\
5761\end{array}$ & $\begin{array}{r}.1695 \\
5761\end{array}$ & $\begin{array}{l}.1746 \\
1147\end{array}$ & $\begin{array}{l}.1901 \\
1147\end{array}$ \\
\hline
\end{tabular}

Note: Regressions also included company dummles, and in the case of the 11 products regressions, SIC sub-class dummles.

We also ran a regression identical to (1) but with a dummy varlable equal to one if the item were sampled by the BLS In the latcer year; results are 
AUDITING THE PRODUCER PRICE INDEX

given In Column (2) of Table 5 . The estimated coefficient on BLSDUMMY varlable is .0292 . with a t-value of 6.61 , Indicating that on average, Items saopled by the BLS grew at an almost 3x larger AAGR than other Items. Notice that this $2.92 x$ coefficlent is almost as large as the $3.06 x$ difference between the growth rate of the official PPI for SIC 28341 (9.09) and that for the DIvisia index of our four-company sample (6.03x). The comparison with the Divisis index is epproprlate here, for the dependent varlable In these regresslons are constructed simllar to the price reletives of the Divisla Index.

For our purposes, it is Inportant to note that the two clearly signiflcant age-related coefficlents frow the age-price regressions (1) and (2) of Table 5 colncide with the two age groups where the BLS sample and fourcompany universe revenue shares differ most dramatically -. under age two and between ages 7 and 10 (see Table 4). Thus there is clear evidence supporting the notion that, with respect to age, Items undersampled by the BLS experience below-average price changes, whlle Items oversampled by the BLS undergo aboveaverage price changes.

To quantify the implications of this combined unrepresentative sampling differential price change by age group phenowenon in unraveling our mystexy in an alternative manner, we have constructed a smple accounting relationship. Let us predict total price growth as a function of revenue shares and agespecific price growth, separately for the Items sampled by the BLS,

$$
\frac{\dot{p}}{\bar{p}}_{B L S}-\sum_{1=1}^{6} w_{1, B L S}\left[\begin{array}{l}
\dot{p}_{1} \\
\bar{P}_{1}
\end{array}\right] \text {. }
$$

and for the four coupantes,

$$
\frac{\dot{p}}{\mathrm{p}}_{\mathrm{COH}}-\sum_{1-1}^{6} w_{1, \operatorname{con}}\left[\begin{array}{l}
\dot{\mathrm{p}}_{1} \\
\overrightarrow{\mathrm{p}}_{1}
\end{array}\right] .
$$


AUDITING THE PRODUCER PRICE INDEX

where the $P_{1} / P_{1}$ are approximated by the regression coefficients frod Table 5 .

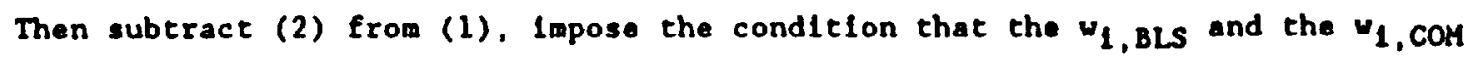
weights ach sum to unlty over the slx age-groups, and collect terms. Thls ylelds the expression

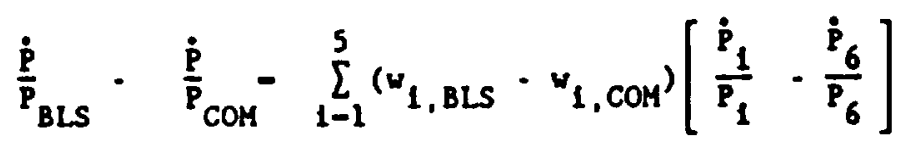

where the 6 subscript refers to the sixth age group (products over age 25 ). According to (3), the difference In predlcted growth rates between the BLS and the four-company (COM) aggregate price Indexes depends on corresponding differences In the $w_{1}$ share welghts times any differences in price changes by age group.

To see how thls relationship helps to understand the difference between AAGR' of aggregate sampled and four-company universe price Indexes, we employ che Table 4 entrles to compute differences In share welghts, and the paraneter estiates of Column (1) In Table 5 to approximate the differentials In price growth by age group. Specifically. to reflect the BLS flxed weights within Cycles I and II, we use as esclmates of the $w_{1}$, BLs weights the arithmetic means of the 1984 and 1988 BLS welghts 1 Table 4 , and as estinates of the $w_{1}$, COM flxed welghts, we use the arlthmetlc mean of the 1984 and 1988 four-company unlverse welghts. Substluting these values into equation (3), and noting that the aggregate price index of BLS sampled ltems grew at an AMGR of $8.94 X$ whlle that for the universe of products at the four companies grew at an AGR of 6.68x, we find that of the $2.26 x$ difference in AAGR's (8.94x - 6.68x), $1.18 \mathrm{x}$ is "explained" by the right-hand side of equation (3) -. differences In share welghts times differentials in rates of price change by age group.

This is a rather satisfying finding, for it implies that if one confines the analysis co differences between two Laspeyres-type Indexes, this very 
AUDITING THE PRODUCER PRICE INDEX

saple accounting $r$ lationship can explain approximately $52 x(1.18 x / 2.26 x)$ of

the difference In AAGR as being due to the BLS oversampling products with above-average price Increases and undersampling of Items with below-average price changes. 23

We have also undertaken a simllar analysis for the systemic antl. infectives sub-class of products. The regression equation we estimated is Given in Column (3) of Table 5. As is seen there, ceteris paribus, products between 7 and 10 , and between 10 and 25 years experlence particularly large price increases. while young products undergo much smaller price changes. Further, when a BLS sapled tea dumy varlable was added to this equation (see Colunn 4 of Table 5), the estimated coefficlent on the BLS dumny varlable is .0560 , with e t-value of 4.66. Hence, other things equal, for systemlc anti. Infectives, on average Items sampled by the BLS grew at an AAGR of about $5.8 \mathrm{x}$ hlgher than all other Items. Moreover, of the $6.28 \%$ difference In AAGR between BLS sampled (8.53x) and four-company universe (2.25x) 1tems, $2.70 x$ is "explained" by the right-hand sfde of equation (4); hence about $43 x(2.70 / 6.28)$ of the discrepancy can be explained by differences in share welghts and differentials in rates of price change by age group. For Cycle I, this proportion Is $367(1.89 / 5.27)$, while for Cycle II It is $38 x(3.26 / 8.54)$.

It is worth enphesizing, however, that in this paper we do not ask why it 1. that the BLS oversamples mediun-age products and undersamples newer products, nor do we pursue why it is that price changes for medium-age products tend to be larger than those for younger products.

\section{YOUNG GOODS AND VARYING WEIGHTS}

Having accounted for a substantal portion of the difference between two Laspeyres-type Indexes on the basis of BLS non-representative sampling, we now curn our attention briefly to an examination of the role of relatively young 
AUDITING THE PRODUCER PRICE INDEX

- Page 24.

goods and varying share welghts in helping to understand the difference between a traditional Laspeyres and varlous other Laspeyres and DIvisla Indexes.

Recall that during Cycle 1 , the BLS sample frame consisted of products chosen In 1981, and that this set of sampled Items remained unt Il January 1988 , when the new Cycle Il sample frame was introduced. Since we do not know what the 1981 revenue shares were, in attempting to mlmlck the BLS procedures using a Laspeyres price index we have employed 1984 fixed quantity welghts during Cycle I, and 1988 fixed quanticy welghts durlng Cycle II. This Implies that goods Introduced after January 1984 but within Cycle I were excluded until 1988, and goods introduced after January 1988 were excluded from Cycle II.

As is seen in Table 6, when this "usual Laspeyres" procedure is employed for all product classes In our four-company data, the AMGR during Cycle I. Cycle II and the cotal clme perlod are $6.58 x, 6.89 x$, and $6.68 x$, respectively, whlle the corresponding offlclal PPI grew at 9.20x, 8.85x and 9.09x. Had the sample frame not changed In January 1988, had the quantity welghts not been altered then, and thereby had all products Introduced after January 1984 been completely excluded, the Laspeyres price Index would haved grown at an AAGR of $9.69 x$ Instead of $6.89 x$ during Cycle II, and $7.58 x$ Instead of $6.68 \mathrm{x}$ over the entire 1/84-12/89 time perlod. Hence, the changing of the sample frame in January 1988 had a substanclal Impact on the Laspeyrea Index.

With the Divisia index, the weights assigned to each product differ by month reflecting changling product market shares, and new goods are Introduced Immediacely, thereby having an impact on the overall index. To consider the Impact of the Cycle II sample frame change, we computed an alternative DIvisiatype aggregate price index in which the set of goods during the Cycle I era consisted only of those present in January 1984, and the set of goods during Cycle II Included only those present In January 1988, 1.e. now goods were excluded except as of January 1988. Results from th1s calculation are also 
AUDITING THE PRODUCER PRICE INDEX

glven In Table 6, where it is seen that allowing revenue share weights to change but restricting the set of products to incumbent ones except for a January 1988 update results in growth rates surprisingly simllar to the traditlonal Laspeyres Index $\cdots 6.36 x$ vs. $6.58 x$ in Cycle I, $7.12 x$ vs, $6.89 x$ during Cycle II, and $6.61 x$ vs. $6.68 x$ overall. However, when the set of products used excludes all new goods (1.e.. all products Introduced after

Table 6

MGR of Aggregate Price Indexes wlth Alternative Treatments of New Goods Cycle I, Cycle II and Overall

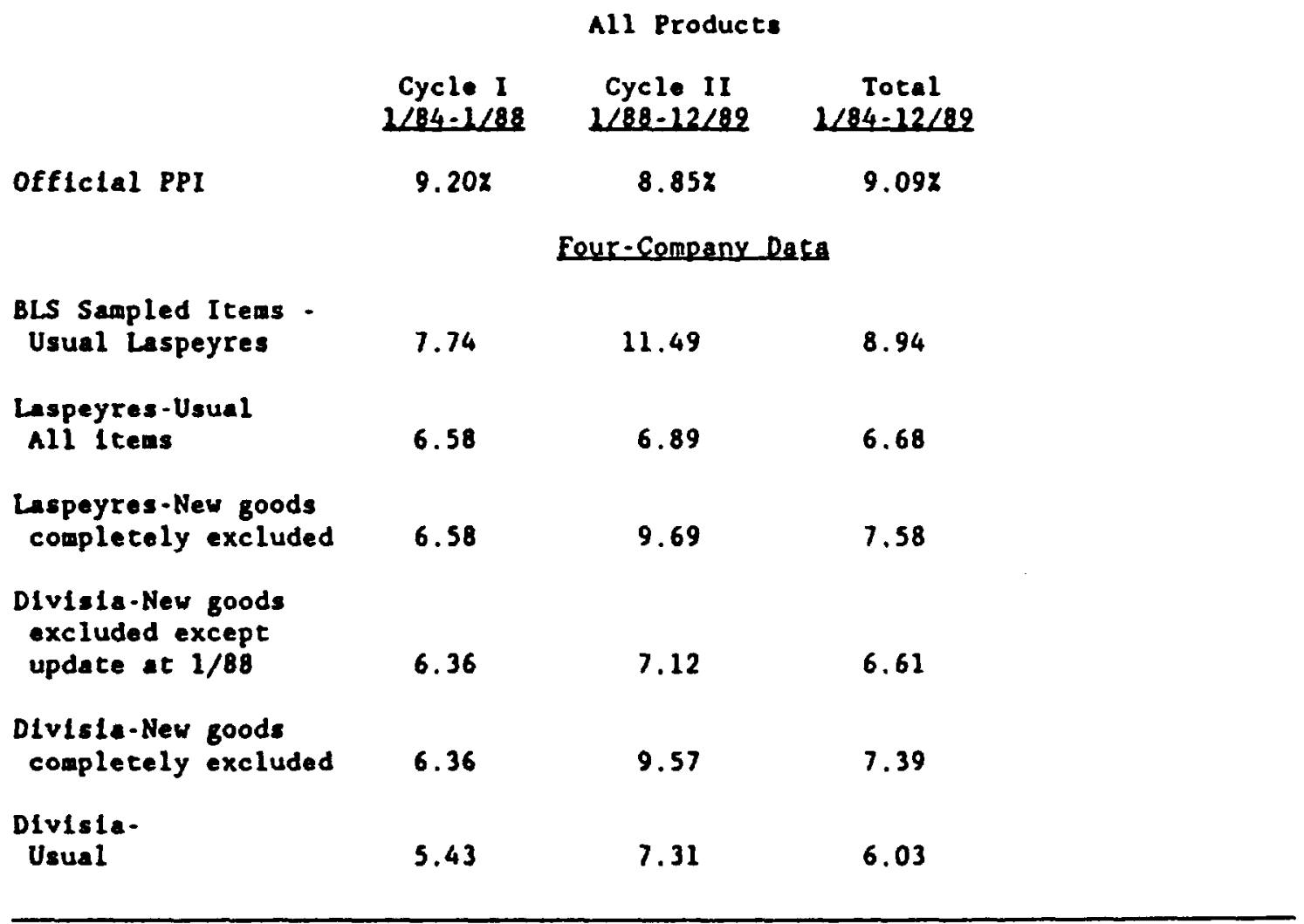

January 1984), the fixed-welght Laspeyres and the varying-welght Divisla yleld more discrepant growth rates .. $6.58 x$ vs. 6.368 in Cycle I, $9.69 x$ vs. $7.12 x$ in Cycle II, and $7.58 \%$ vs. $6.61 \%$ overall. Finally, when new goods are Introduced 
AUDITING THE PRODUCER PRICE INDEX

into the Divisia price Index as soon as is feasible, the MGR's fall considerably .. to $5.43 \mathrm{x}$ in Cycle I, $7.30 \mathrm{x}$ in Cycle II, and $6.03 \mathrm{x}$ overall. ${ }^{24}$

We conclude, therefore, that differences in MGRs between the Laspeyres and Divisia Indexes are rather modest, provided that computacions ere undertaken over an Identical set of goods. However, when the set of goods Included In the computations Incorporates new and relatively young products Immediately, the resulting Divisia Indexes grow at a considerably slower race than do the fixed-welght Laspeyres Indexes that exclude these new goods. In the pharmaceutical Industry, the role of new and relatively young goods is a signiflcant one, and falling to Incorporate new goods prompty into the price Index calculations results in upward blased growth rates.

\section{CONCLUDING REMARKS}

Our focus in this paper has been on why the official BLS price index grows approximately $50 x$ more rapidly (9.09x vs. 6.03x) than a Dlvisla Index, where the latter is computed using date on 2,090 products sold by four of the ten largest firms in the US pharmaceutical Industry. These four firms comprised approximately $24 x$ of total domestic Industry sales in 1989.

The ovidence we have presented suggests that, In teras of sampled Items. the difference cannot be attributed to the four firns being unrepresentative of the Industry as a whole, for growth rates of prices for 1tems sampled by the BLS at the four flrms are very close to that of the officlal PPI (8.94X va. 9.09x). Moreover, when IMS daca are employed for a sub-class of products (systemlc antl-Infectives) encompassing almost the entire universe of products, the difference In AAGR becomes even larger - $6.26 \%$ for the officlal PPI vs. $1.54 x$ for the Divisia index. An Incidental finding is that for the 241 exact product matches between the IMS and four-company data sets, growth rates of prices are similar - a similarlty that glves us some confidence in using the 
AUDITING THE PRODUCER PRICE INDEX

IHS data as a proxy for producer level prlce growth. Finally, differences between Industry-wide and the four-firm product share distributions do not help explain the discrepancy, for differentials In AACR's are essentially unaffected when Census-BLS Industry sub-class weights are employed Instead of those besed on the four-firm data.

What is it about the BLS procedures that on average appear to also the smaller prlce Increases of representative transactions? Our analysis has demonstrated that a substantial proportion (about $50 x$ ) of the difference In MGR's between prices reported by the four firms to the BLS and transactions prices for the four-firm universe of products can be attributed to the fact that the BLS tends to undersample younger products that experience less than average price Increases, and oversample mediun-age Items that undergo aboveeverage price Increases. Why it is that the BLS undersanples younger and oversamples nedium-age products is not clear to us, nor do we address in this paper the interesting 1ssue of why medium-age products experience larger price increases than younger items.

We also find that differences in AAGR between the Laspeyres and DIvisla Indexes are rather modest provided that computatlons are undertaken over an Identical set of goods. However, when the set of goods Included In the computations incorporates new and relacively young products, the resulting Divisla price Indexes grow at a considerably slower rate than do the fixed. weIght Laspeyres price Indexes. In the US pharmaceutIcal Industry from 1984 through 1989, the role of new and relatively young goods was a ignificant one, and falling to Incorporate new goods prompty into the price index calculations appears to have resulted in upward blased growth rates.

It is worth emphasizing that the research reported here neglects entirely the fact that generic drugs could be linked to their patented antecedents, and that new drugs Incorporating quallty changes could be connected to their 
AUDITING THE PRODUCER PRICE INDEX

- Page 28 .

predecessors via hedonlc procedures. 25 since generlc drugs axe treated by the

BLS as entrely new products and are not IInked to patented progenitors, and

Ince generics tend Intelally to be priced at lower levels than thelr patented

competltors, we belleve that the MACR's of price Indexes properly IInking

generics would be even lower than those reported in this paper. Work on this

lssue is currently underway involving aystemic anti-Infectives, as is an

exploratory effort to determine whether it is feasible to undertake hedonic

price analys la for cardlovascular drugs. 
AUDITING THE PRODUCER PRICE INDEX

APPENDIX A:

FURTHER DETAILS ON THE PRODUCER PRICE INDEX FOR SIC 28341

Before 1978 the Producer Price Index was known as the tholesale Price Index (UPI). The UPI orIgInated from an 1891 U.S. Senate resolution authorizing the Senate Comittee on Finance to investigate the effects of the tarlff laws "upon the lmports and exports, the growth, development, and prices of agriculcural and manufactured articles at home and abroad." 26

The BLS calulates the PPI according to a modifled Laspeyres formula In which the value of base perlod quantitles at current period prices is divided by the value of base period quantities at (perhaps temporally different) base perlod prices, 1.e.

$$
I_{t}-\left|\sum Q_{a} P_{c} / \sum Q_{a} P_{0}\right| \cdot 100-\left(\sum Q_{a} P_{0}\left(P_{c} / P_{0}\right) 1 / \sum Q_{a} P_{0}\right] \cdot 100
$$

where $Q_{a}$ represents the quantity shipped during the welght-base perlod, $P_{t}$ is the current price of the commodity, $P_{0}$ is the price of the commodity in the comparison period, the summation is over 1 goods, but 1 subscripts are onltted. 27 Note that this index 15 a welghted average of price relatives $P_{t} / P_{0}$

In the main toxt of thls paper we outlined the process employed by the BLS in choosing establishments and products to sample. To understand this sampling process becter, we now follow the BLS procedure and discuss its two distinct atages, In which the overall ald is to make the probability of selection proportional to a product's value of shipments (VOS). The first stage consists of choosing a randon sample of establishments, drawn from Unemploywent Insurance files. In the second stage, In principle specific 
AUDITING THE PRODUCER PRICE INDEX

- Page 30 .

products of that establishment are chosen with probabllity proportional to vos, -l though in practice some products for SIC 2834 are certainty selected to ensure coverage of Important 1tems. 28 We now sumarlze these two stages.

All PPI's are routinely subject to monthly reviston every month for four monchs after original publication (usually on the second or third friday of the wonth following the reference month), to raflect late reports and corrections by company respondents. After four months, Indexes are considered final.

The sampling frame for establishment: is drawn from the Unemployment Insurance data flles (as updated and refined by BLS personnel), and In almost 211 cases reported employment determines the probability of inclusion. ${ }^{29}$ Although use of VOS to choose the establishment sampling frame would be proferable, the BLS justifles using employwent as a proxy for vos in the first stage since employment flgures are more widely avallable for establishmente than are data on VOS; ${ }^{30}$ noreover, BLS asserts that UI "...ls used as a proxy in sampling aince the number of employees tends to be correlated with the revenue of a Proflt Maximizing Center within a particular SIC." 31 If prices for several establlshments are set at one location (called a Profit Maximizing Center), then the establishments (referred to as a cluster) are considerad to be one establishment, and the reported employment flgures are approprlately summed.

Once an establishment has been selected, In the second stage BLS fleld representative visits $1 t$ and conducts an intervlew designed to select the ftens to be priced and to collect base prices and value welghts. In theory, the probability with which a product is selected, given cholce of the establishment and the number of quotes assigned to 1t, 1s proportional to Its vos over the twelve months prior to the intervlew. In this disaggregation process, In princlple, vos-based sampling probabillties are employed, but detalled information on price-determining characteristics is required for only a small 
AUDITING THE PRODUCER PRICE INDEX

subset of products. This economy of required detall reduces the reporting burden on cooperating companies, and resulte in an initiation interview that is "usually completed within 2 hours." 32

Within the disaggregation process, several additional steps occur. First. all products are categorlzed Into broad product classes. A running total of the percent of vos for each category is formed, and the number of price quotes to be taken from withln each category is determined by randonly choosing a flrst percentile level and equally spacing the remaining quotes to be chosen.

For example, suppose there are three product categorles and that five quotes are to be chosen for the establishment as a whole. Let the first category account for $50 \mathrm{x}$ of the vos, the eecond for 30x. and the third for 20x; hence the running total is $50 x, 80 x$ and $100 x$. Since five quotes are to be chosen, a randoa percentlle level from 1 to 20 is selected (note that 100x/5 20x). Suppose this randon percentlle level is 15.33 Then the additional four quotes are equally spaced at intervals of 20; In this case, at 35, 55, 75 and 95. Because the 15th and 35th percentiles both fall within the first segment of the running total $(0 x-50 x)$, two quotes will be chosen from the first category. Simllarly, 55 and 75 fall within the second segment, so two quotes will be chosen from the second category. Finally, one quote will come from the third category. This process of disaggregation is repeated within each category from the first stage until an Individual product Involved in a particular transaction is identified. The resulting unique transaction is then recorded in detall so that future price quotes can be accurately identifled by the reporting establishment.

As was noted earller, in some cases selected product categorles are "certainty sanpled" or "certainty selected". This can occur if it is felt by the sLS that some item is of particular importance, or may be so in the future. 
AUDITING THE PRODUCER PRICE INDEX - Page 32 .

In the 1987 sample for specifled companles, both diabotes and cancer theraples are certainty selected. In this type of certainty selection, one Iten fron within the choson category is selected using normal disaggregation procedures (•.8., within SIC 2834119 for cancer theraples, or within SIC 2834127 for diabetes theraples), the VOS for the entire category 1s subtracted from the vos of the establishment, the number of remainlng selections is reduced by one, and the disaggregation process is begun again from the beginining (wlthout the certainty selected category). This procedure is repeated for any additlonal cortainty selected items. A second type of certainty sampling occurs whenever the percentage of VOS for a product class exceeds the sanpling interval at that level of disaggregation.

For the pharmaceutical and paper alll Industriea, the Cycle II disaggregation procedure differed from that for most other industries in two respects. First, rather than allowing the establishment to determine the classes of products for the first step of the disaggregation process. the BLS provided a table of product categorles. In most Industries no more than elght cacegorles are defined at each level of disaggregation, but In SIC 28341 there are 48 products within the prescription pharmaceutlcals section. The other difference from normal disaggregation procedures is in the handing of the second type of certalnty selection, mentloned at the end of the provlous paragraph. The nornal disaggregation procedure mlght result in "multiple hits", 1.e. It might choose alven product more than once. To avold this, If a category is wider than the sampling interval, then a product is chosen by disaggregation within the category, the vos is deducted fron the overall vos for the establishment, and the process is started again with the certalnty selected ltem removed. Hence multiple hits are not possible. ${ }^{34}$

Once the Intelation Interview is completed and the Itens for which price quotes are to be obcalned are decerwined, repricing occurs with reporting 
AUDITING THE PRODUCER PRICE INDEX

taking plece chrough the mall. Fron this the BLS obtains a time serles of monthly price quotes for each 1tem sampled, defined In such way so as to make the Item transacted and the transaction constant over time.

To construct PPI's, the sampled products are classifled into cells, typlcally at the seven to nine digle SIC level; the within cell Index welghts are the vos for the establishment divided by the number of quotes from the establishment. Note that an Item with small vos is given the same withincell welght as an 1 ten with a larger voS, but that thls is consistent with probabllley sampling proportonal to VOS, for the small Ited essentially represents wany other suall ltews which, when combined, have the same probability of selection as a single, larger ltem with the same vos. As we understand $1 t$, the within call index is a fixed-base Laspeyres index adjusted from month to wonth so as to show no change when product deletions occur. Aggregated between-cell Indexes are then created by welghting within-cell Indexes by voS within the cells produced within the same Industry; these vos are taken fron the U.S. Department of Commerce. Census of Manufacturers. 35 Thus, shlpment values for the same products made in other industries do not enter the welghting structure. 36 The cocal value of shipments for each Industry is then distributed anong the products or other revenue sources produced by chat Industry. thereby aliminating the need for Indirect welght Imputations, a practice that was common under the pre-1978 methodology of the PPI. 
EOOTNOTSS

Irving Fisher [1922], p. 360.

${ }^{2}$ Specifically, fixed welghte are linked In January 1988, corresponding with the BLS change In moving fron Cycle I to Cycle II sampling.

${ }^{3}$ Thls paper extends and bullds on the preliminary findings and conjectures reported In Bernde, Grlilches and Rosete [1990].

4hls lssue hes been oxamined by George J. StIgler and James K. KIndahl [1970]. who found that overall, although there was little difference between the erand of BLS and transactlone prices fron 1957 to 1961. fron 1961 to 1966 the BLS price Index rose about $0.7 \%$ more rapldly than an Index based on transactions prices. For the ethleal pharasceutical proparations industry, however, Stlgler-Kindahl found no eppreclable difference between ILS and transactions prlces.

SMuch of the material In this Appendix 1s taken from Berndt, Grillches and Rosete $(1990)$.

${ }^{6}$ Some products were deleted from or added to this 11 st during the $1984-89$ time perlod.

There 1s sone confuston concerning the treatnent of production in Puerto RIco. A substantial amount of pharmaceutical preparations production occurs In Puerco Rico, and whlle production establishments are not sampled by the BLS in Puerto Rlco, fron conversations with conpany officlals we aro led to bollove that in reporting data to the BLS the flrms treat Puerto Rlco as dometic.

8 Since no Industry publication provides a classiflcation of prescription pharmecouticals by 7.dIgit SIC code, we vorked with company officials and exanined the Physiclans' Desk Reference [1990] and Drug Facts and Comparisons [1991] in undertaking such a classification. In somo cases, however, Judgment was necessary, for occastonally a drug could be envlsaged as belng in more chan one sub-cless. Overall price and seles data were given us for 2,551 products, of which 207 were classifled as non-prescription. In eddition, we were unable to assign detalled SIC clesses for 254 products. The nonprescription ltems accounted for only $1.10 \mathrm{x}$ of total revenues, and the unclassifled ltems accounted for but $0.53 x$ of total revenues.

${ }^{9}$ IMS Amerlca, $660 \mathrm{~W}$. Germantown P1ke, Plymouth Meeting, Pennsylvania 19462 (telephone $215 \cdot 834-5000$ ).

${ }^{10}$ Thls discussion is based in large part on sumary information provided us by IMS America in the "front pages" of audit information for U.S. Drugatore and U.S. Hospital.

11 Average prices are often lower to hospltals than to other outlets.

12 Overall, 341 matches were made between IMS and 4-company products. 100 vere deleted, as 45 had no common-month prices, 38 had few and highly volatile prices reported by the companies, and 17 were entrants or exits where movements of Inftial or final sales by producers through the distribution chain caused poor contemporaneous tracking in the IMS data.

${ }^{13}$ The AAGR of the DIvista index (using four-company revenue weights) for IMS 
date was 4.12X, whlle that for the matched four-company producte was $3.27 X$. since the four-company Divisia for all products in SIC 2834111 grows at but $1.20 \mathrm{x}$ per year, we interpret the higher growth rates of these common 1 tems. as reflecting the fact that the matched products onlt new goods and therefore represent more mature, established products. Recall from the previous footnote that typically new goods are poorly tracked by IMS as they InItially enter the distribution chain.

14 It might be noted, however, that contemporaneous correlations of monthly $10 \mathrm{~g}$ price changes between IMS and company data are typlcally very low . often less than 0.02 . However, for annualized prices, the revenue-welghted correlations exceed 0.5 .

15Parallel MCR's over the same 10/84 - 12/89 tIme perlod for the four-company products In SIC 2834111 are 1.962 for the Laspeyres and $1.15 \mathrm{x}$ for the Divlsia. We had expected the IMS prices to grow at a lower rate than those In the four-coapany date, In part because the IMS data include generic drugs. Why this Inequality occurs is a toplc worthy of further consideration.

16 Monthly total revenue data by therapeutic class were purchased from IMS.

17This smoothing procedure was employed to mitigate the problem of "drift" that occurs with chalned indexes such as the Divisla. For further discussion, see Berndt, Gr111ches and Rosett (1990), as well as Barzel [1963), Frisch [1936] and Szulc [1983].

18 This Laspeyres calculation uses company quantlties as welghts, and links thea In Jenuary 1988 to reflect the BLS splice between Cycles I and II. For Cycle I, the AAGR of reported prices was 7.74X, while for transactions prices it was 8.97x; for Cycle II. the respective growth rates are 11.497 and $10.69 x$.

${ }^{19}$ For Cyclo I, reported and average transactions prices of SIC 2834111 sampled Iteas grew at an AMR of $7.64 \mathrm{X}$ and 7.637 . respectively, while for Cycle II the growth rates are $10.43 \%$ and $10.64 \%$.

${ }^{20}$ See, for example, W. Erwin DLewert [1988] and the references clted therein.

21 Alternative presentations of the same product introduced at different dates are treated as such, 1.0.. we do not treat alternative treatments as all belng Introduced at the time the Initial presentation was brought to market.

22 Revenue shares are computed as the arithmetic mean of the shares in the two years.

23then a Inflar analysis is done separately for Cycles I and, we find that of the $1.16 x$ difference In MGR in Cycle I, the right-hand side of equation (4)

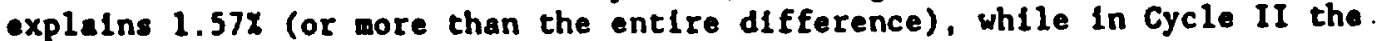
relationship explains $1.15 \%$ of the $4.60 \%$ difference in MAGR's.

24 It would have been desirable to undertake a sinilar analysis using the IMS data, but at this polnt in time we have not been able to obcain data on product Introduction dates for the Items In that data set.

${ }^{25}$ For an example in the context of personal computers, see Berndt-Gr 11 iches [1990].

${ }^{26}$ See U.S. Senate Comnlttee on Finance [1893]. 
27 Note that the summation councer is not specifled In (1), and generally requires an additional subscrlpt. Also, the BLS Handbook (BLS, Bulletin 2285 [1988], P. 130) states that "The expression $\left(Q_{a} P_{0}\right)$ represents the welght In value forn, and the $P$ and $Q$ elements (both of which orlginally relate to perlod "a" but are adjusted for price change to perlod "O") are not derived separately."

${ }^{28}$ In U. S. Department of Labor (undated, a), It is stated that "For specified companies, both cancer therapy and dlabetes preparation druga are being certainty selected."

29 DLecussions with BLS personnel Indlcate that In sowe cases where value of shipaent data is Intact and complete for establishante. vOS rather than UI daca are used to compute probablilties of Inclusion.

$30_{A s} H 111$ (1987, p. 583) notes, "By law, every enployer in the U.S. Is required to report the number of people employed and to purchase insurance whlch w1ll cover the employer's unemployment benefit liability. As a result the UI file data are fairly complete. The continued existence of the UI file 1s also assured, thereby ensuring continued avallabllity of a consistent frane for sampling. The UI flle contalns such Inforaction as the establishment's nawe, the SIC In which It is classifled, the county and state in which it is located. and tts number of enployees. This flle le explicitly etratifled according to Industry classification and thus provides Individual Industry frames which forn the basis for the PPI frames."

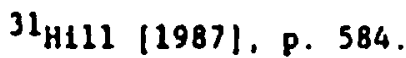

${ }^{32}$ U. S. Department of Labor [1988, p. 128].

${ }^{33}$ Randon numbers are presented on the bottoms of pages in the forms filled out by BLS fleld representatives.

${ }^{34}$ However, there is some ambigulty here. Although the wording in the BLS discussion of special disaggregation procedures (U. S. Departient of Labor [1986a]) explicitly states that the entire cell 1 s discarded once the cercainty selection occurs, our ample fron one company concains multiple selections from individual cells.

35 An adjustment is made for inter. and Intra-Industry transfers to rewove nonfinal product values from the welghts, thereby obtalning net output values of shlpments as welghts. Currently the adjustment factor is based on the 1977 Input-Output tables from the Bureau of Economle Analysis, U. S. Department of Commerce.

${ }^{36}$ For Eurther discussion, see U. S. Department of Labor [1988, p. 129]. 


\section{REFERENCES}

Barzel, Yoram |1963), "Some Observations on the Index Number Problem," Econometrica, 3:1. July, 391-399.

Berndt, Ernst R. and ZvI GrIllches [1990], "Price Indexes for Mlcrocomputers: An Exploratory Study," Cambridge, MA: National Bureau of Economic Research, Working Paper No. 3378, June.

Berndt, Ernst R., ZvI Grillches and Joshua Rosett [1990], "On the Accuracy of Producer Price Indexes for Pharwaceutical Preparations: An Audit Based On Detalled Firm-Speclfic Data, - Cambridge, MA: National Bureau of Economic Research. Working Paper No. 3490, October.

Dlewert. W. Erwin [1988], "The Eerly History of Price Index Research," Cambridge, MA: National Bureau of Economic Research, Horking Paper Ho. 2713. September.

Drue Facts and Comoarlsons [1991]. St. Louls, Mo: J. P. Lippincott Company. Faces and Comparisons Division.

Fisher, Irving [1922]. The Making of Index Numbers, Cambridge, MA: Houghton Miffiln Company.

Frisch, Ragnar [1936], "Annual Survey of General Economic Theory: The Problem of Index Numbers," Econometrlea, 4:1, January, 1-38.

Cousen, Sarah, Kathy Monk and IrwIn Gerduk [1986], Rroducer Price Measurement: Concepts and Hethods, Weshington, DC: U. S. Department of Labor, Bureau of Labor Statistics, xerollth, June.

Hill, Klaberley Dalley [1987], "Survey Deslgn In the Producer Price Index," 1987 Proceedings of the Section on Survey Research Methods of the Anertcan Stethetical Associatlon. Washington, DC: American Statiotical Assoclation, pp. $583 \cdot 588$.

Hulten, Charles R. [1973], "Divisia Index Numbers," Econometrica, 41:6, November, 1017-1025.

Phystclans' Desk Reference (1990), Oradell, NJ: The Medical Econonics Company Inc.

StIgler, George J. and James K. KIndahl [1970], The Behavlor of Industrlal Prices, NBER General Sarles No. 90. New York: Columbia Unlversity Press for the National Bureau of Econonic Research.

Szulc, Bohdan J. [1983], "Linking Price Index Numbers," In W. Erwin Diewert and Claude Montmarquette, eds.. Prfee level Messurement. Proceedings from a Conference Sponsored by Statistics Canada, Ottawa: Minister of Supply and Services Canada, PP. 537.566, October.

U. S. Department of Labor [1989]. "The Producer Prlce Index: An Introduction to 1te Derivation and Uses, Washington, DC: Bureau of Labor Statistics, March. 
AUDITING THE PRODUCER PRICE INDEX

U. S. Department of Labor [1988], "Producer Prices," chapter 16 fron BLS Handbook of Mechods, Hashington, DC: Bureau of Labor Statistics. Bulletin 2285, Apr11, Pp. 125-137.

U. S. Departaent of Labor [1986a], Daca Collectlon Manual: Producer Price Index. Washingron, DC: U. S. Government Printing Office for the Bureau of Labor Statistes, 1986-491-543-54349. July.

U. S. Department of Labor (1986b). Producer Price Heasurenent: Concepts and Hechods, Hashington, DC: Bureau of Labor Statistlcs. June.

U. S. Senate Comittee on Finance (1893), tholesale Prices Hares and Iranspercacion, Senate Report No. 1394, "The Aldrich Report," Part I, 52nd Congress, 2nd Session, March 3, 1893. 